\title{
Pitman B. Potter, China's Legal System,
}

Cambridge, Malden, Polity Press, 2013, 267 pp.

\section{Rogier Creemers}

\section{CpenEdition}

\section{Journals}

Electronic version

URL: http://journals.openedition.org/chinaperspectives/6735

DOI: $10.4000 /$ chinaperspectives. 6735

ISSN: 1996-4617

\section{Publisher}

Centre d'étude français sur la Chine contemporaine

\section{Printed version}

Date of publication: 1 June 2015

Number of pages: 61-62

ISSN: 2070-3449

\section{Electronic reference}

Rogier Creemers, «Pitman B. Potter, China's Legal System, », China Perspectives [Online], 2015/2 | 2015, Online since 01 January 2017, connection on 22 September 2020. URL : http://

journals.openedition.org/chinaperspectives/6735; DOI : https://doi.org/10.4000/chinaperspectives. 6735

(c) All rights reserved 
- too late - to the producers (private plots of land restored, the unit of accounting delegated down to the work team level, the contract responsibility system, etc.) than by the decision - which also came too late - to send 20 million recently-arrived city dwellers back to the countryside and import grain from capitalist countries such as Australia and Canada. These imports helped provide food for the city dwellers, who were now fewer in number, in turn making it possible to reduce the collections demanded from producers. The latter were nevertheless left with the task of feeding those returning from the cities, in waves staggered over several years. This departing manpower was missed less acutely in industry because the end of agricultural exports and the import of grain meant it was no longer possible to import machine tools: industry was condemned to mark time even before the leaders had reversed the priorities by placing "agriculture at the forefront." A birth control campaign was also started in 1962, and - until a major turnaround in 1978 - the rural exodus was restricted, as a result of which the level of urbanisation increased only minimally, from $17.3 \%$ in 1962 to $17.92 \%$ in 1978 (p. 230). The lessons to be learned from the disaster are analysed in the epilogue, but to my eyes, Chapter 4 ("Preventing Urban Famine by Starving the Countryside, 1959-1962") represents the best section of the book.

On the other hand, Chapters 5 to 7, which make up the third section ("Famines on the Periphery"), are less important and, in my opinion, too long. They compare Ukraine, which was struck harder than any other region of the USSR by the famine of 1932-1933 (Kazakhstan was proportionally hit harder still in 1931), and Tibet, where the losses were less serious than those in Anhui, Henan, and many other provinces populated almost exclusively by the Han. These three chapters deal less with the famine itself than with the contradictory accounts concocted by the official historiography and the Ukrainian or Tibetan nationalists. Interest therefore shifts to questions concerning the autonomy, separatism, or secession of outlying regions occupied by national minorities, a subject that is no doubt interesting in itself, (4) but that diverts us from the essential subject and contributions of the book.

The final shortcoming of the book relates to its few instances of inaccuracy or inconsistency. China's population in 1964 loses 13 million people between page 229 (704 million) and the following page (691 million), which is an excusable error, corresponding roughly to the natural annual growth at the time. Table 4.3 (Average annual consumption of grain per inhabitant in the cities and countryside, China 1952-1966) and the text on page 133 raise a more serious problem: $362 \mathrm{jin}$ is probably a typographical error that should read 312 jin, but on the next line, an incorrect calculation matches up 386 jin annually with 493 grams per day (instead of 529). Incidentally, the incorrect calculation is possibly closer to reality than the 386 jin taken from Table 4.3, which indicates, probably incorrectly, that urban consumption was higher in 1960 than in 1958.

These are trivialities compared to the gems unearthed elsewhere, starting with two evocative graphs on pp. 88 and 245. That on p. 88 illustrates the operation of the unified grain purchase and sale system that was in force from 1953 to 1960; that on p. 245 shows the hierarchy of grain consumers, placing at the bottom the producers of rice and wheat consumed by the upper levels. In addition to these examples, in no particular order, are Kropotkin's warning (past revolutions failed because they were unable to feed the population during times of radical change, p. 46), the comparison between the Soviet internal passport and the hukou (p. 65), and the millions of deaths that could have been avoided by an earlier end to grain exports (in the USSR, all of the deaths resulting from hunger, p. 247). Furthermore, solidly reasoned theoretical discussions introduce or provide the crowning achievements of the empirical research. To cite but a few examples here, the author refutes the theories amplifying the peasant resistance and its impact (pp. 78-82, 149, and 152), and offers a critical examination of the theories of Armartya Sen and Jean Drèze. Sen's famous "entitlement approach" (the distribution of commodities and the denial of rights were more significant factors in the famine than the reduction or lack of availability of food) is ultimately shown to have its limitations, without being entirely disproven (pp. 149-152 and 246). The theories of Drèze and Sen as to how democracy is more capable of preventing famines than authoritarian regimes succumb much more quickly to the author's reasoning (pp. 237239). His arguments are as convincing as they are learned, the Soviet case following the Chinese case before itself being encapsulated by other examples (India and Africa) and other centuries (Imperial China and its system of organising assistance).

\section{Translated by Will Thornely.}

I Lucien Bianco is professor emeritus at EHESS (School for Advanced Studies in Social Sciences), Paris (biancosud@gmail.com).

4. As far as the USSR is concerned, the standard reference is Terry Martin, The Affirmative Action Empire: Nations and nationalism in the Soviet Union, 1923-1939, Ithaca, London, Cornell University Press, 2001.

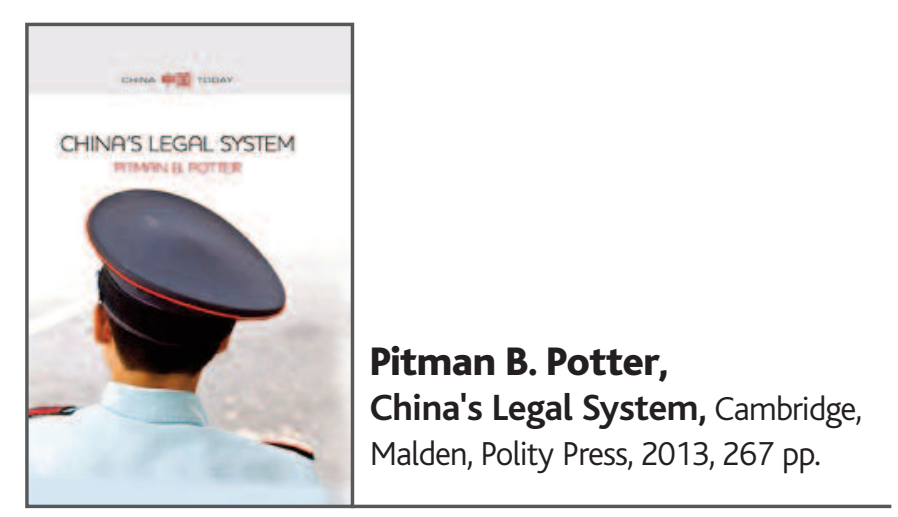

\section{ROGIER CREEMERS}

$\mathrm{H}$ ow does one begin to understand Chinese law? How does one do justice to the complexity of the legal (re)construction process that has taken place since the late 1970s? Observers must navigate between the Scylla of teleological approaches that too easily assume trajectories towards ill-defined notions of rule of law and democratisation, and the Charybdis of historical determinism. They must do justice both to a continuing dominant view of law as an instrument of state power and the agency of lawyers, judges, academics, and activists inside and outside of the legal system who seek to develop and apply their own conceptions of professionalism and justice. They must explore the influences of socialism and foreign legal transplants, and the impact of autochthonous traditions and concepts. They must cater to the preconceptions of legal scholars, for whom the relative immaturity of China's legal system is sometimes difficult to conceive, and those of China experts, who are often predisposed to seeing law as merely a continuation of politics and power and lacking autonomous existence. 
Enter Pitman Potter's most recent book China's Legal System, which seeks to provide the sort of primary introduction to this topic that has, thus far, been sorely lacking. Potter's approach in this volume is to present China's legal system as a historical artefact, constituted through the vagaries of twentieth century statecraft. In the first section, Potter leads us along the legal development from the last days of the Empire through the Republic and on through the People's Republic. He succinctly identifies continuities, such as the reinterpretation of relational justice, and disruptions, paying particular attention to Maoist nihilism and the subsequent restoration of some idea of law as central to contemporary governance.

The next three sections address how law has served efforts to generate political stability, economic prosperity, and social development. Under the heading of political stability, Potter, like China's rulers, lets Party leadership precede a discussion of the renewed formal, constitutionally defined structures of state power, including the National People's Congress, administrative agencies, courts, and legal practice. Lastly, he situates criminal justice and administrative detention in a broader coercive order aimed at deterring behaviour deemed to endanger stability. The section on economic prosperity explains how, after the demise of class struggle as a dominant political concern, the ideological emphasis shifted to the "productive forces" in the process of development. Starting from notions of "corporatism" and "clientelism," Potter from the outset qualifies the extent to which law has been able to provide predictability and certainty for economic actors. Furthermore, by contrasting economic law as a mode of state policy implementation and as a facilitation of autonomous economic interaction, Potter puts his finger precisely on the nub of some of the most conflicting elements in the relationship between law and the market. At a more technical level, this section addresses the fundamental elements of contract and property law, as well as taxation and its relationship to economic growth. Turning to questions of social development, Potter points at the profound conflicts between the single-minded pursuit of economic growth and social concerns, which he divides into traditional and emerging categories. On the traditional side, we find labour relations, healthcare, education, and the rights of women and ethnicities. Emerging concerns include media and the Internet, environmental protection, and corporate social responsibility. Yet, in spite of efforts to create regulatory norms in these fields, Potter acutely draws into question the permanence and consistency of the government's commitment to ensuring implementation in practice.

The last section is dedicated to Chinese interaction with international law and engagement with international regimes. It ably describes the ambivalence with which these matters were approached: during the Mao era, China denounced international law as bourgeois, yet sought to join the UN. After 1989, China was ostracised from international society, yet rapidly expanded its dialogues in areas as diverse as trade and human rights. China's WTO membership has had a profound influence on its domestic legal order, yet in other areas, such as environmental regulation, China has sought to limit its commitments.

This volume is principally directed at students, and must therefore be evaluated as such. Potter's narrative recounts little that isn't known to more experienced observers and scholars of Chinese law, nor does it offer novel theoretical insights. But that is not the point. Rather, this book must be assessed on the contribution it could make to providing the next generation of China law researchers with the initial tools and concepts with which to tackle the issues mentioned earlier in this review. Within these parameters and the approach that Potter has taken, this book succeeds admirably. At all times, Potter avoids unnecessary jargon and abstruseness, and provides useful discussion questions and reading suggestions at the end of every chapter. Substantively, the nuance and sensitivity of his previous works shines through. Perhaps most importantly, Potter shies away from making grand statements on the future of Chinese law, leaving it to the reader to ponder the complex issues he raises.

The answer to the question of whether this reviewer would use this book in an introductory course on Chinese law is unreservedly yes. However, it is also necessary to point out that despite the breadth of the issues tackled in this book, it is not comprehensive. It tells us relatively little about, for instance, the processes of legislation and enforcement, or about black letter law in many areas. This criticism should, nevertheless, not be laid at Potter's feet. Rather, the pithy and incisive insights with which this volume is replete should enable a course organiser to set deeper discussion topics, supplemented with more specialised reading.

\section{Dogier Creemers is Rubicon Scholar at the Centre for Socio-Legal Studies, University of Oxford (rogier.creemers@csls.ox.ac.uk).}

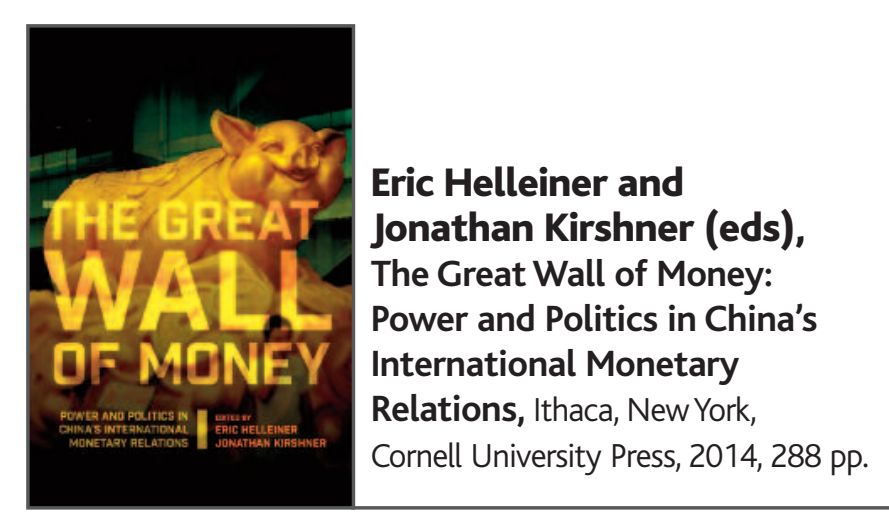

\section{ADRIEN FAUDOT}

T his collection is edited by two experts in international political economy, their association having already produced reference works on international monetary relations, notably The Future of the Dollar (2009). The two academics repeat the experience, this time focusing on China's monetary relations and the internationalisation of its currency, the renminbi (RMB). The book seeks to understand the political stakes in China's international monetary relations and the type of power it is acquiring from them (p. 2).

Benjamin Cohen's chapter considers the strategy China is pursuing in internationalising its currency - how far will the RMB go? - bearing in mind the failures of previous competitors to the dollar. The vagueness of the response is due to ignorance of the strategy of Chinese power, knowing that it cannot be integrated into the monetary system dominated by the United States as were West Germany, Japan, and the Euro Zone, as China is not a historical ally of the American hegemon and "it is not at all clear that the Chinese are ready to dance" (p. 40). While strong economic incentives could link China to the current international monetary system by according some rights and admitting it to the "club" of international powers, geopolitical considerations could upset this economic logic and make China adopt a conflictual attitude vis-à-vis the existing monetary order. 